\title{
WPLYW DOŚWIADCZEŃ Z KONFLIKTU GRUZIŃSKO-ROSYJSKIEGO Z 2008 ROKU NA WIZJĘ WSPÓŁCZESNEGO BEZPIECZEŃSTWA MIĘDZYNARODOWEGO. WYBRANE PLASZCZYZNY
}

Działania wojenne, do jakich doszło w lecie 2008 roku na terytorium Gruzji, były punktem kulminacyjnym w paśmie narastającej wrogości występującej w relacjach pomiędzy Gruzją a Federacją Rosyjską. Region, który w 2008 roku stał się polem walki zbrojnej, niemalże od momentu upadku ZSRR podlegał częstym zawirowaniom politycznym. Nierzadko spory pomiędzy państwami lub wewnątrz nich kończyły się zastosowaniem siły militarnej np. wcześniejsze działania wojenne w Abchazji i Osetii Południowej w latach 1990-1993 ${ }^{1}$. Podstaw wybuchu tzw. wojny sierpniowej ${ }^{2}$ należy doszukiwać się przede wszystkim w istniejącej w regionie Kaukazu sieci zależności oraz w wykreowanych tam płaszczyznach rywalizacji między państwami. Dlatego należałoby uznać, że wojna między Federacją Rosyjską i Gruzją nie była przypadkowym konfliktem zbrojnym, tylko wynikiem zamierzonych, wcześniejszych działań obu państw. Szczególne znaczenie dla wytworzenia swoistej nowej jakości w relacjach w regionie miała tzw. rewolucja ró $\dot{z}^{3}$. Jej bezpośrednim wynikiem stało się skierowanie polityki zagranicznej na wektor prozachodni, przez nowe władze Gruzji z prezydentem Micheilem Saakaszwilim na czele. Szczególne znacznie miało wręcz symboliczne wyrażenie chęci rozpoczęcia drogi do uzyskania członkostwa w Unii Europejskiej i NATO przez Gruzję. Władze Federacji Rosyjskiej uznały, że takie przeorientowanie polityki gruzińskiej zagraża strefie wpływów, budowanej w regionie przez rosyjską obecność polityczną, najlepiej wyrażoną w działaniach Wspólnoty Niepodległych Państw oraz militarną, która objawiała się m.in. utrzymywaniem silnego zgrupowania w ramach Północnokaukaskiego Okręgu Wojskowego. Symultanicznie do starań Gruzji mających na celu zbliżenie z zachodem, Federacja Rosyjska rozpoczęła działania uprzedzające postępowanie Gruzji. Najistotniejsze było w tym przypadku wzmocnienie pozycji Ro-

1 Zob. szerzej: A. Petersen, The 1992-93 Georgia-Abkhazia War: A Forgotten Conflict, „Caucasian Review of International Affairs” 2008, Vol. 2(4), s. 187-199; South Ossetia - Background, GlobalSecurity.org, http://www.globalsecurity.org/military/world/war/south-ossetia-3.htm (17.08.2009).

2 Nazwa pochodzi od miesiąca, w którym prowadzone były działania wojenne.

3 Rewolucją róż zostało określone bezkrwawe przejęcie władzy zaistniałe w 2003 roku w Gruzji. W listopadzie 2003 r. na fali protestów ulicznych zainicjowanych przez opozycję, na czele której stał m.in. późniejszy prezydent Gruzji Micheil Saakaszwili, od władzy został odsunięty prezydent Eduard Szewardnadze. Zob.: G. Kandelaki, Georgia 's Rose Revolution. A Participant 's Perspective, United States Institute of Peace Special Report, http://www.usip.org/files/resources/sr167.pdf(17.08.2009). 
sji, jako głównego rozgrywającego w regionie, przy jednoczesnym osłabieniu na różnych płaszczyznach Gruzji. Stąd też nie było zaskoczeniem stanowcze opowiedzenie się Federacji Rosyjskiej po stronie nieuznawanych quasi państw - Abchazji i Osetii Południowej $^{5}$, których kwestia negatywnie wpływała na nowo kreowany wizerunek Gruzji jako potencjalnego państwa kandydata do wstapienia do UE i NATO. W dodatku obie strony tzn. Gruzja i Rosja niewątpliwie uznawały kwestię Osetii Płd. i po części Abchazji za cenny argument $\mathrm{w}$ przypadku własnych zbrojeń oraz w perspektywie polityki wewnętrznej. Abchazja i Osetia Płd. stały się w ten sposób bezpośrednio kartami przetargowymi w polityce gruzińskiej i rosyjskiej, a skutkiem tego było rozpoczęcie otwartego konfliktu militarnego. Próba sił do jakiej doszło w Osetii Południowej nie rozwiązała jednak żadnego z problemów w regionie, a jedynie wykazała, że użycie sił zbrojnych może być akceptowalną reakcją jednego z państw na działania drugiej strony. Chociaż wojna trwała relatywnie krótko jej podłoże polityczne oraz aspekt militarny mogą być podstawą budowy analizy roli wyboru sojuszników w przypadku budowania bezpieczeństwa państwa, potrzebie odpowiedniego kreowania przez każde państwo własnego systemu obronnego, dopasowanego do konkretnych wymogów geopolitycznych, czy też odpowiedniego doboru narzędzi w przypadku rozwiązywania sporów politycznych.

\section{SIEĆ ZALEŻNOŚCI A GLÓWNE KIERUNKI RYWALIZACJI}

Współczesny system relacji między państwami w regionie Kaukazu wytworzył się wraz z rozpadem ZSRR ${ }^{6}$. Od tego momentu stosunki w ramach dotychczas jednego

4 Abchazja - jest separatystyczną republika, znajdującą się de iure na terytorium Gruzji, ze stolicą w Suchumi. Populacja Abchazji to około 250000 osób. Separatystyczna republika odłączyła się od Gruzji po krwawej wojnie, która wybuchła w lipcu 1992 r. tuż po ogłoszeniu przez Abchazję niepodległości. Pod koniec 1993 r. w wyniku działań Federacji Rosyjskiej rozpoczęły się negocjacje pokojowe pomiędzy walczącymi stronami, których finałem było wprowadzenie do Abchazji sił rosyjskich dysponujących mandatem Wspólnoty Niepodległych Państw, do Abchazji skierowano również obserwatorów z ramienia ONZ. Abchazja ma wszelkie atrybuty niepodległego państwa w postaci własnego parlamentu, prezydenta (Sergey Bagapsh), konstytucji, rządu, sił zbrojnych i systemu sądowniczego. Zob.: Regions and territories: Abkhazia, BBC News, http://news.bbc.co.uk/2/hi/europe/3261059.stm\#overview (17.08.2009).

5 „Osetia Południowa (Republika Południowej Osetii, według publikacji gruzińskich - powiat cchinwalski) -obszar w północnej Gruzji obejmujący tereny istniejącego do 1991 roku Południowoosetyjskiego Obwodu Autonomicznego, wchodzącego w skład ówczesnej Gruzińskiej Socjalistycznej Republiki Sowieckiej. Osetia Południowa leży w północnej Gruzji, w środkowej części Wielkiego Kaukazu, jej granica przebiega około $40 \mathrm{~km}$ na północny zachód od Tibilisi, od północy graniczy z rosyjską Republiką Osetii Północnej wchodzącą w skład Federacji Rosyjskiej. Powierzchnia Osetii Południowej to około $3900 \mathrm{~km}^{2}$, stolicą jest Cchinwali. Jest to kraina górzysta przecięta rzeką Wielki Liachwi. Populacja to obecnie około 90 000, w zdecydowanej większości są to Osetyjczycy (Gruzini uciekli po wojnie 1990-1992 i ostatnim konflikcie z 2008 roku). Powstanie Republiki Osetii Południowej proklamowano 28 listopada 1991 roku. Obecnie głową „,państwa” jest prezydent Eduard Djabejewicz Kokoty, na czele rządu stoi premier Asłanbek Bułajcew. W 2007 roku Gruzja powołała „Tymczasową Administrację Południowej Osetii", na czele której stanął Dimitri Sanakojew. Siedzibą tego organu była miejscowość Kurta, która jednak w wyniku ,wojny sierpniowej” została zajęta przez Osetyjczyków i Rosjan”. Cyt. za: K. Kubiak, Wojna gruzińska (1), „Militarny Magazyn Specjalny Komandos” 2008, nr 12, s. 45.

${ }^{6}$ Nie można pominąć aspektu historycznego, ściśle związanego $\mathrm{z}$ podstawami szeregu trwających na Kaukazie konfliktów i sporów. Np. odwołania się do tzw. wojen kaukaskich z XVIII 
państwa -ZSRR, zastapiły oddziaływania pomiędzy wieloma nowymi i niepodległymi podmiotami stosunków międzynarodowych. W dodatku część grup narodowościowych, które w okresie rozpadu ZSRR, nie uzyskały samodzielności wyraziło chęć określenia własnej szerokiej autonomii lub wręcz zbudowania niepodległości, nawet w drodze działań zbrojnych. Każde nowe państwo, w tym także Gruzja, oprócz niepodległości otrzymało w spadku po komunizmie trudną sytuację wewnętrzną oraz zadawnione konflikty na płaszczyźnie regionalnej, wynikające z różnego rodzaju zatargów pomiędzy poszczególnymi państwami. Całość obrazu trudnej sytuacji Kaukazu, dopełniło pojawienie się aktywnej i wyrażającej imperialne ambicje na płaszczyźnie regionalnej, Federacji Rosyjskiej. Rosja stawiała sobie główny cel, jakim było dążenie do trwałego ugruntowania roli głównego rozgrywającego w relacjach pomiędzy państwami kaukaskimi. Odwoływano się w ten sposób do charakteru Federacji Rosyjskiej jako spadkobiercy interesów dawnego ZSRR na tym obszarze. W ten sposób obok działań częstokroć skłóconych ze sobą i rywalizujących mniejszych państw, zaobserwować można było także akcje podejmowane przez jedno ze światowych mocarstw. Sytuacja była tak skomplikowana, że w latach dziewięćdziesiątych XX wieku ,zwarły się zatem w zbrojnych starciach Armenia i Azerbejdżan o Górny Karabach, a Inguszetia z Osetią Północną o tzw. Prigorodnij Rejon. Gruzja uwikłała się również w wewnętrzne konflikty z Abchazją i południowymi Osetyjczykami. Najkrwawsza wojna toczyła się jednak od 1994 roku do czerwca 1995 r. między Rosją a małą Republiką Czeczenii [...]"7. Nie do pominięcia, w analizie zmian regionalnych, stały się wcześniej wyciszone wewnątrz ateistycznego ZSRR kwestie religijne. Religie nie tylko różnicowały ludność zamieszkującą dane państwa, ale również były wykorzystywane w podsycaniu starych i kreowaniu nowych antagonizmów ${ }^{8}$. Należałoby uznać, że Kaukaz był po upadku ZSRR najbardziej konfliktogennym post-sowieckim regionem.

Rosja wkraczając w okres postzimnowojenny nie wyzbyła się, tradycyjnego w czasach ZSRR, postrzegania w swej polityce zagranicznej wybranych regionów świata, jako własnych stref wpływów. Tzw. bliska zagranica ${ }^{9}$ miała być kształtowana wedle polityki rosyjskiej, co też wielokrotnie kolidowało z tendencjami niepodległościowy-

i XIX w. przez narody Kaukazu walczące z ekspansją rosyjską w regionie. Jednakże można także dostrzec pewną relatywizację aspektu historycznego na przełomie XX/XXI w., który niejako został zaprzęgnięty do pragmatycznych działan stricte politycznych, ukierunkowanych na osiagnięcie bieżących celów aniżeli np. idei wolności ludów Kaukazu. s. 5 .

Z. Czarnotta, Z. Moszumański, Największe bitwy XX wieku. Czeczenia 94-95, Warszawa 1995,

${ }^{8}$ Szczególnie uwidoczniły się tarcia religijne w obliczu konfliktu azersko-ormiańskiego o Górny Karabach czy też w przypadku działań Federacji Rosyjskiej w Czeczenii.

9 Richard Pipes napisał, że „brak świadomości dużej części Rosjan, że rządzą wieloma narodami nie-rosyjskimi (według spisu ludności ZSRR z 1926 r., jedynie 54 proc. obywateli kraju stanowili Rosjanie), miał poważne konsekwencje. Gdy w 1991 r. ZSRR przestał istnieć, Rosjanie zrozumieli, że utracili imperium i nie do końca wiedzą, kim są. Aby odzyskać zachwianą tożsamość, popierają teraz wysiłki rządu Władimira Putina zmierzające do odbudowy rosyjskiej hegemonii nad «bliską zagranicą». Takie jest uzasadnienie niechęci, z jaką Rosja rozstaje się z byłymi posiadłościami. Wielka Brytania nie miesza się w sprawy Indii, Holandia nie interweniuje w Indonezji. Ale Rosja wykorzystuje wszelkie środki nacisku, by jej dawne kolonie nie poszły własną drogą, a szczególnie by nie związały się sojuszem z Zachodem”. Cyt. za: R. Pipes, Nieznośnie bliska zagranica, „Wprost”2006, nr 51/52, wydanie internetowe http://www.wprost.pl/ar/100009/Nieznosnie-bliska-zagranica/ (22.10.2009). 
mi, popularnymi po upadku ZSRR m.in. na Kaukazie. Przede wszystkim w rosyjskiej polityce zauważalna była obawa przed rozszerzeniem idei wyłaniania się nowych państw w regionie, w wyniku krystalizacji dążeń niepodległościowych nowych grup narodowościowych, tworzących mozaikę etniczną Kaukazu. W przypadku zachodnich rubieży ZSRR, sytuacja była opanowana, gdyż po powstaniu Białorusi, Ukrainy i państw nadbałtyckich proces dalszego rozdrobnienia terytorium Federacji Rosyjskiej był mało prawdopodobny. Wręcz przeciwne uwidoczniły się nurty w nowo powstałych państwach tj. Ukraina i Białoruś, odwołujących się do ścisłego związku z Rosją. W przypadku Białorusi zbliżenie z Federacją Rosyjską osiagnęło nawet formę strukturalną w postaci zbudowania tzw. Związku Białorusi i Rosji. Jednakże sytuacja na Kaukazie była diametralnie różna od tej na rosyjskiej zachodniej granicy. Ponadto na Kaukazie, wbrew nawet największym problemom społeczno-ekonomicznym, jakie targały Rosja, państwo to nadal pozostawało główną determinantą dla polityki wszystkich innych państw. Przede wszystkim Rosja, jako mocarstwo funkcjonujące w Radzie Bezpieczeństwa ONZ z łatwością mogło blokować działania społeczności międzynarodowej. Jednakowoż organizacje tj. NATO i WE/UE, stanowiące wyznaczniki dobrobytu i bezpieczeństwa Zachodu, nie miały woli działania na rzecz aktywnego uczestnictwa w rozwiązywaniu problemów Kaukazu. Dlatego Federacja Rosyjska jako jedyne mocarstwo miało chęć i przede wszystkim środki oddziaływania na region. „Kaukaz uznano za »miękkie podbrzusze« Rosji, gdzie nie można tolerować jakichkolwiek separatystycznych ruchów"10. Argument powstrzymywania separatyzmu stał się sztandarowym hasłem rosyjskich działań na Kaukazie, który został zastąpiony dopiero po 11 września 2001 roku niejako rosyjską wersją wojny z terroryzmem. Kazusem, który skupił niczym pryzmat zainteresowanie rosyjskie Kaukazem była próba zbudowania niepodległej Czeczeńskiej Republiki Iczkerii. Wówczas jeszcze mocniej podkreślono rosyjskie przekonanie o potrzebie aktywności w regionie, obecne już wcześniej wśród elit władzy Rosji. Czeczenia, która ogłosiła niepodległość już w 1990 r. i wydawało się, że będzie kolejnym niepodległym państwem w regionie, stała się symbolem powrotu do imperialnych wzorców w polityce rosyjskiej. Federacja Rosyjska, chociaż nadal osłabiona, w przypadku Czeczenii przystapiła do działań. Zdaniem władz rosyjskich pierwsza wojna czeczeńska miała wyeliminować zagrożenie, płynące z podsycania przez Czeczenię dążeń niepodległościowych innych narodów, co było sprzeczne z interesami rosyjskimi $\mathrm{w}$ regionie ${ }^{11}$. Reakcja rosyjska przerodziła się $\mathrm{w}$ otwarty konflikt zbrojny, trwający z przerwami niemalże od 1994 roku i którego części nazywane są pierwszą trwającą w latach 1994-1995 oraz drugą, rozpoczętą w 1999 roku, wojną czeczeńską. Można nawet stwierdzić, iż w przypadku Kaukazu nastąpiło swoiste sprzężenie zwrotne, bowiem Rosji zależało na utrzymywaniu pewnej dozy niestabilności,

${ }^{10}$ Z. Czarnotta, Z. Moszumański, Czeczenia 94-95..., op. cit., s. 9.

11 Można w tym miejscu wskazać na możliwość przeszczepiania wzorca czeczeńskiego na inne autonomiczne regiony znajdujące się w ramach Federacji Rosyjskiej. Pierwszy prezydent Czeczenii Dżochar Dudajew, używając tzw. Konfederacji Górskich Narodów Kaukazu pragnął ograniczenia interesów rosyjskich w obrębie Północnego Kaukazu. Federacja Rosyjska, pragnąc utrzymać pozycję oraz potencjalnie rozszerzyć własne możliwości wpływania na inne państwa regionu potrzebowała także wykazania własnej siły, która mogłaby zostać użyta w przypadku realizacji polityki w regionie uznawanym za własną strefę wpływów. 
w przypadku regionu, który miał być kontrolowany, zaś postępujący wraz z wybuchem wojny wzrost napięcia zmusił Rosję do większego zaangażowania sił i środków. W ten sposób Czeczenia na trwałe wpisała się w rosyjską politykę, będąc jednym z głównych tematów m.in. kampanii prezydenckiej Władimira Putina z 2000 roku. Rosja także rozszerzała własną aktywność na Kaukazie pod wpływem determinant ekonomicznych. Wraz ze wzrostem cen surowców naturalnych, w tym przede wszystkim ropy naftowej, kluczowym zadaniem rosyjskiej polityki stało się uzyskanie wpływu nie tylko na te państwa postsowieckie, które dysponowały odpowiednimi złożami kopalin, ale również na te, przez terytorium których przechodził tranzyt surowców. Jednak bez utrzymania linii przesyłowych, znajdujących się częstokroć na terytoriach innych państw, samo dysponowanie złożami nie byłoby w pełni skutecznym narzędziem w przypadku prowadzenia rosyjskiej polityki surowcowej. Bodźcem, o którym nie można zapomnieć analizując podstawy polityki Federacji Rosyjskiej w regionie, był również symboliczny zamiar utrzymania pozycji potęgi światowej. Jako że Rosja nie była w stanie, z racji problemów ekonomicznych, prowadzić tak ekspansywnej polityki globalnej, jaka charakteryzowała ZSRR, to Kaukaz wydawał się idealnym miejscem do ukazania światu własnej potegi. Finalnie Federacja Rosyjska miała stać się dla wszystkich państw znajdujących się w kaukaskiej strefie wpływu głównym wektorem i determinantą w kształtowaniu ich polityki.

Aby móc realizować własne zamierzenia w obrębie Kaukazu, Federacja Rosyjska wykorzystywała szereg narzędzi, począwszy od dyplomacji, a skończywszy na użyciu sił zbrojnych. W pierwszej kolejności uwagę zwraca element znacznej przewagi militarnej Federacji Rosyjskiej nad każdym państwem Kaukazu i to pomimo widocznych problemów całych rosyjskich sił zbrojnych. Na Kaukazie to nadal Rosja występuje z pozycji siły. Przejawem uznania wagi Kaukazu we własnych planach strategicznych było chociażby rozlokowanie przez Federację Rosyjską silnego zgrupowania wojsk, operującego w ramach tzw. Północnokaukaskiego Okręgu Wojskowego ${ }^{12}$. Oprócz oddziałów pełniących zadania stricte bojowe, niektóre jednostki z sił rosyjskich pełniły rolę sił pokojowych w regionie, co zaowocowało w przypadku Osetii Płd. działaniem na pierwszej linii walk. Oprócz głównych sił zbrojnych podległych Ministerstwu Obrony w regionie własnymi formacjami bojowymi i milicyjnymi dysponowało także Ministerstwo Spraw Wewnętrznych Federacji Rosyjskiej ${ }^{13}$ i Federalna Służba Bezpieczeń-

12 Według Ministerstwa Obrony Federacji Rosyjskiej Północnokaukaski Okręg Wojskowy odpowiada za obronę terytorium Rosji oraz jest miejscem kreowania działań antyterrorystycznych. - http://www.mil.ru (22.10.2009). Północnokaukaski Okręg Wojskowy ma dowództwo w Rostowie nad Donem. „Okręg wojskowy to w rosyjskim modelu zarządzania siłami zbrojnymi struktura administracyjno-operacyjna. W przypadku Okręgu Północnokaukaskiego, na terytorium którego stacjonują cztery wielkie jednostki szczebla dywizji (19. DZmech. - Dywizja Zmechanizowana, 42. DZmech., 20. DZmech. Gwardii oraz 7 DPD - Dywizja Powietrznodesantowa), elementy operacyjne to Grupa Wojsk Rosyjskich na Zakaukaziu (odpowiedzialna m.in. za okupację i przeprowadzenie działań pacyfikacyjnych w Czeczenii) oraz 58. Armia (dowództwo w Władykaukazie)". Cyt. za: K. Kubiak, Wojna gruzińska (1), op. cit., s. 49. O Północnokaukaskim Okręgu Wojskowym zob. szerzej North-Caucasian Military District, GlobalSecurity.org, http://www.globalsecurity.org/military/world/russia/vo-north-caucasian.htm (17.08.2009); M. Gawęda, Wojska rosyjskie w wojnie z Gruzja, „Nowa Technika Wojskowa” 2008, nr 10, s. 47-48.

13 Zob. szerzej: T. Szulc, Wojska Wewnętrzne MWD FR, „Raport Wojsko-Technika-Obronność”, 2006, nr 3, s. 68-76. 
stwa. Sama obecność tak silnych kontyngentów różnych wojsk rosyjskich wywierała presję na polityków innych państw regionu. Oczywistym było, że w przypadku działania wbrew interesom rosyjskim można byłoby spodziewać się rosyjskiej presji politycznej, która jak to miało miejsce w przypadku Czeczenii, mogła prowadzić w ostatecznym etapie nawet do otwartej militarnej interwencji. W przypadku Gruzji można odnotować, iż jeszcze przed upadkiem ZSRR uwidoczniła się rola sił zbrojnych późniejszej Rosji w kreowaniu sytuacji tego państwa. Jednostki jeszcze radzieckie, a później podobnie już rosyjskie, nie zachowały obojętności w przypadku prób pierwszych interwencji gruzińskich w Abchazji i Osetii Płd. na początku lat dziewięćdziesiątych XX wieku. Część z jednostek radziecko/rosyjskich nawet bezpośrednio walczyła przeciwko stronie gruzińskiej. Miało to miejsce w szczególności w przypadku Osetii Płd. Najważniejszym jednak stało się w obu przypadkach, doradzanie oraz przekazywanie stronie abchaskiej i osetyjskiej dużej ilości uzbrojenia ${ }^{14}$, bez którego nie byłoby możliwe prowadzenie działań wojennych przeciwko Gruzji. Jednocześnie wraz z wygaszeniem obu konfliktów, to właśnie jednostki rosyjskich sił zbrojnych stały się trzonem dyslokowanych do Abchazji i Osetii Płd. tzw. sił pokojowych. O wadze, jaką wywarł czynnik rosyjskiej aktywności militarnej dla kształtowania się polityki w regionie, może świadczyć osłabienie frakcji niepodległościowej w polityce gruzińskiej, którą reprezentował Zwiad Gamsachurdia ${ }^{15}$. Opowiadał się on za unifikacją całości terytorium Gruzji, jednak niepowodzenia militarne w Abchazji i Osetii Płd., których powodem były przede wszystkim działania sił rosyjskich, doprowadziły do jego usunięcia przez opozycję w samej Gruzji. Federacja Rosyjska zmusiła Gruzinów do uległości, stając się instancją do której rząd gruziński musiał się odwołać aby wygasić konflikty trawiące państwo. Siły rosyjskie, jako trzon sił pokojowych, stały się również elementem ugruntowującym stan permanentnego konfliktu, gdyż zarówno Abchazja, jak i Osetia Płd. mogły pod ich opieką rozwijać własne jednostki wojskowe i milicyjne. Ponadto obok obecności wojsk rosyjskich w Abchazji i Osetii Płd., istotnym elementem rozgrywki w relacjach gruzińsko-rosyjskich były również rosyjskie bazy wojskowe na terytorium Gruzji ${ }^{16}$. Ich funkcjonowanie bezpośrednio przekładało się na aspekt bezpieczeństwa całego państwa gruzińskiego, a więc także na długofalową strategię polityków gruzińskich. Jednakowoż obok chyba najwidoczniejszego czynnika militarnego, należałoby wskazać również na inne narzędzia, którymi posługiwała się Federacja Rosyjska do ugruntowywania własnej pozycji w regionie. Do jednego z najbardziej skutecznych, a zarazem pragmatycznych posunięć, należy zaliczyć utrzymywanie niestabilności wewnętrznej w państwach regionu oraz podtrzymywanie

${ }^{14}$ W obliczu prób oderwania się od Gruzji przez Osetię Płd. i Abchazję istotna stała się pomoc wojskowa udzielona przez wojska radzieckie/rosyjskie. „Osetyjczycy uzyskali wsparcie Moskwy, otrzymując od Armii Radzieckiej broń i amunicję. [...], zaś stacjonujące na terenie Abchazji wojska rosyjskie udostępniły odpłatnie tworzącym się abchaskim jednostkom wojskowym broń i amunicję". Cyt. za: T. Szulc, Zaktamana wojna, op. cit., s. 5.

156 stycznia 1992 roku Zwiad Gamsachurdia uciekł z Gruzji do Armenii. Następnie przebywał w autonomicznej republice Czeczenii-Inguszetii. Jego następcą został Eduard Szewardnadze, zostając nowym prezydentem Gruzji.

${ }_{16}$ Zob.: N. Sokov, The Withdrawal of Russian Military Bases from Georgia: Not Solving Anything, Monterey Institute of International Studies, June 2005, s. 2-4. 
stanu napięcia w kontekście antagonizmów występujących między państwami regionu. Przykład podjęcia decyzji o uznaniu Abchazji i Osetii Płd. dopiero w wyniku wojny sierpniowej, wskazuje na fakt rozgrywania tymi zagadnieniami w relacjach z Gruzją. Do tego dochodzą działania wywiadowcze w państwach regionu, infiltracja władz i instytucji czy też tworzenie oraz wspieranie pewnych grup i partii politycznych odpowiadających za utrzymywaniem dobrych relacji z Rosją. Kluczowym elementem w rozgrywce regionalnej były także różnego rodzaju aspekty ekonomiczne. Federacja Rosyjska była m.in. rynkiem zbytu dla wielu towarów pochodzących chociażby z Gruzji, stąd stosowanie barier celnych czy innych ograniczeń w handlu mogło być użyte w działaniach wymierzonych przeciwko państwom pragnącym działać wbrew zamiarom Federacji Rosyjskiej. Należy nadmienić, że przemysł większości państw regionu oparty jest na technologiach radzieckich, a więc Rosja dysponowała możliwościami kreowania transferu technologii. Innym ważnym punktem w prowadzeniu własnej polityki w regionie, były działania dyplomatyczne wyrażone m.in. w funkcjonowaniu Wspólnoty Niepodległych Państw. Tak więc Rosja miała zarówno motywy do kontrolowania regionu Kaukazu, jak i bezpośrednio różnego rodzaju narzędzia do wdrażania własnych wizji w relacjach z poszczególnymi państwami kaukaskimi. Rosyjska polityka była w tym kontekście pragmatyczna i ujmowała się w klasycznym postrzeganiu strefy wpływów mocarstwa.

W obrębie zarysowanej wcześniej rosyjskiej kaukaskiej strefy wpływów, znalazła się od początku niepodległa już od 1990 roku Gruzja. Jednakże główny kierunek gruzińskiej polityki odbiegał w sposób znaczący od radzieckiej, a później rosyjskiej wizji Kaukazu. Istotnym bodźcem było przede wszystkim istnienie wśród Gruzinów silnego poczucia własnej państwowości, która ma za sobą długą tradycję ${ }^{17}$. Stąd też działania rosyjskie ukierunkowane na kontrolowanie sytuacji w niepodległej Gruzji, były zdecydowanie mniej skuteczne aniżeli miało to miejsce w przypadku innych państw Kaukazu. Pierwszym sprawdzianem samodzielności był wybór Zwiada Gamsachurdii na prezydenta Gruzji. Będąc w czasach ZSRR więzionym dysydentem politycznym, był on zdecydowanym przeciwieństwem dla postsowieckich elit politycznych, które dominowały w innych niepodległych państwach Kaukazu. Jego samodzielność była problemem dla odbudowy całej strefy wpływów, szczególnie, że opierała się ona na podkreśleniu samodzielności narodu gruzińskiego. Głoszone w Gruzji idee niepodległościowe znajdowały oddźwięk także w innych państwach, stając się przykładem choćby dla Czeczenów. Dlatego nie było zaskoczeniem, iż ,został on [Z. Gamsachurdia - JR] jednak wkrótce obalony w wyniku puczu przygotowanego i przeprowadzonego przez rosyjski Specnaz GRU. W styczniu 1992 roku musiał zbiec do Czeczenii"18. Jednakże samo obalenie Z. Gamsachurdii nie gwarantowało utrzymania Gruzji w strefie wpływów. Dlatego strategicznym i rozgrywanym w perspektywie długookresowej działaniem było, ze strony rosyjskiej, wywołanie niestabilności wewnętrznej w samej Gruzji. Tego rodzaju polityka osiagnięta została poprzez wsparcie dążeń Abchazji, Osetii Płd. i Adżarii do uzyskania samodzielności od Gruzji. Państwo gruzińskie było

${ }_{17}$ Zob.: K. Kubiak, Wojny, konflikty zbrojne i punkty zapalne na świecie, Warszawa 2005, s. $67-68$.

18 P. Wdowiak, Gruziński egzamin demokracji, „Międzynarodowy Przegląd Polityczny” 2007, nr 1, s. 217. 
niejako otoczone potencjalnymi płaszczyznami konfliktów, które co najważniejsze determinowała postawa Federacji Rosyjskiej. Nowy prezydent Gruzji Eduard Szewardnadze, po nieudanej wojnie domowej, zdając sobie sprawę z braku możliwości rozwiązania siłowego problemu separatystycznych regionów przystał, niejako na utrzymywany w interesie Federacji Rosyjskiej status quo. Symboliczne stało się przystąpienie Gruzji do Wspólnoty Niepodległych Państw i uznanie stacjonowania wojsk rosyjskich, określanych jako siły pokojowe, w Abchazji i Osetii Płd. Do roku 2003 sytuacja nie ulegała zmianie, mimo wyraźnego zbliżenia Gruzji z Zachodem. Należy zaznaczyć, iż było to raczej zbliżenie nieuznane przez stronę rosyjską za ważne dla całokształtu jej strefy wpływów. Działania E. Szewardnadze ukierunkowane na Zachód miały bowiem przede wszystkim na uwadze raczej trudną sytuację ekonomiczną Gruzji, aniżeli chęć przewartościowania systemów sojuszy. Ówczesny gruziński prezydent zdawał sobie sprawę ze słabości własnej pozycji w systemie władzy, co przy kazusie Gamsachurdii obalonego w imię interesów rosyjskich, hamowało jakąkolwiek próbę gwałtownego odejścia od głównej linii interesów Rosji w regionie. Należy jednak zaznaczyć, że w mniejszym stopniu niż strona rosyjska, również strona gruzińska podejmowała działania wymierzone w rosyjskie interesy w regionie. Zastępczym frontem stała się Czeczenia, która wraz z II wojną czeczeńską skupiła na sobie uwagę głównego nurtu polityki rosyjskiej na Kaukazie. Kluczem stał się, znajdujący się na terytorium Gruzji Wąwóz Pankiski, który spełniał rolę bezpiecznego zaplecza dla bojowników czeczeńskich walczących z Rosją. Można uznać, że brak kontroli gruzińskiej nad tym obszarem wynikał nie tylko z braku sił i środków, ale również pewnego cichego przyzwolenia dla działań czeczeńskich. $\mathrm{O}$ wykorzystywaniu przez stronę gruzińską problemu czeczeńskiego świadczyć mogło m.in. użycie bojowników czeczeńskich w strategicznym Wąwozie Kodorskim w 2001 roku $^{19}$. Sytuacja uległa przeobrażeniu wraz ze zmianami politycznymi w Gruzji w 2003 roku. Nowe władze Gruzji, na czele z prezydentem Micheilem Saakaszwilim jednoznacznie opowiedziały się za zmianą dotychczasowego charakteru relacji gruzińsko-rosyjskich. Filarami samodzielności miało stać się rozpoczęcie procesu dochodzenia Gruzji do struktur politycznych Zachodu - UE oraz militarnych - NATO. Było to ewidentne naruszenie koncepcji rosyjskiej strefy wpływów i spowodowało ostrą reakcję ze strony Federacji Rosyjskiej. Gruzja także po 2003 roku rozpoczęła aktywne próby rozwiązania problemów Abchazji, Osetii Płd. i Adżarii. W przypadku Abchazji ,po objęciu władzy w 2003 roku ekipa gruzińskiego prezydenta Micheila Saakaszwilego rozpoczęła szereg działań zmierzających do rozwiązania konfliktu. Były to zarówno propozycja autonomii dla Abchazji (daleko posunięta autonomia kulturalna, ekonomiczna, np. strefy wolnego handlu, stanowisko wiceprezydenta Gruzji dla Abchaza, prawo weta w sprawach dotyczących Abchazji itp.) odrzucona przez Abchazję, jak i działania siłowe (m.in. zajęcie w 2006 roku wysokogórskiego, strategicznego Wąwozu Kodorskiego i zainstalowanie tam przebywającego dotąd

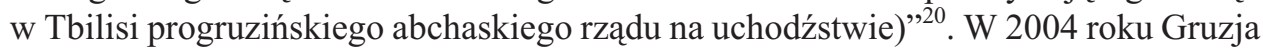

19 Zob.: K. Kubiak, Wojny, konflikty zbrojne i..., op. cit., s. 69-70.

20 W. Bartuzi, K. Pełczyńska-Nałęcz, K. Strachota, Abchazja, Osetia Południowa, Górski Karabach: rozmrożone konflikty pomiędzy Rosja a Zachodem, Raport Specjalny Ośrodek Studiów Wschodnich im. Marka Karpia, 9.07.2008, s. 5. 
osiagnęła znaczący sukces przywracając kontrolę nad Adżarią. W przypadku dalszych sukcesów w rozwiązaniu kwestii spornych i wyeliminowania czynnika Abchazji i Osetii Płd. w kontroli działań gruzińskich, Rosja mogła spodziewać się nie tylko utraty własnych wpływów w samej Gruzji, ale także w innych państwach regionu, szczególnie że Gruzja nawiązała relacje ze Stanami Zjednoczonymi na płaszczyźnie niespotykanej wcześniej. Dobre stosunki z USA uwidoczniły się w najbardziej widoczny sposób w pomocy dla gruzińskich wojsk oraz sił bezpieczeństwa. Dowództwo Europejskie Sił Zbrojnych Stanów Zjednoczonych (EUCOM) i Dowództwo Sił Operacji Specjalnych Stanów Zjednoczonych pilotowały dwa programy pomocy w rozwoju możliwości obronnych i bezpieczeństwa Gruzji - Program Szkolenia i Wyposażenia Gruzji oraz Program Bezpieczeństwa i Operacji Stabilizujących ${ }^{21}$. Prowadzono także liczne wspólne ćwiczenia wojskowe. Jedne z nich o kryptonimie Immediate Response w 2008 r. zakończyły się tuż przed wybuchem działań wojennych w Osetii Płd. Wzrost gospodarczy po 2003 r. pozwolił także Gruzji na samodzielne wzmacnianie zdolności bojowych sił zbrojnych oraz sił bezpieczeństwa. Nawiązane zostały liczne kontakty w zakresie modernizacji i zakupów uzbrojenia m.in. z Ukrainą i Izraelem. Z Izraela pochodziło nie tylko uzbrojenie, ale również liczna grupa kontraktorów, którzy zajmowali się szkoleniem sił gruzińskich ${ }^{22}$. Reformowanie gruzińskich sił zbrojnych i bezpieczeństwa ograniczało przewagę militarną Rosji, zaś potencjalne umocowanie się wpływów Stanów Zjednoczonych w tym państwie wyeliminowałoby ją całkowicie. $\mathrm{W}$ tle podejmowanych rozgrywek politycznych i działań militarnych istniał również kluczowy problem transportu surowców naturalnych oraz kwestia dywersyfikacji przez Zachód źródeł pozyskiwania surowców, takich jak ropa i gaz ziemny.

Podsumowując, po 2003 r. Gruzja była największym zagrożeniem dla rosyjskiej strefy wpływów umiejscowionej na Kaukazie. Federacja Rosyjska dysonowała zaś zdolnościami i możliwościami rozwiązania głównych problemów bezpieczeństwa niepodległej Gruzji. Stąd też oba państwa miały nie tylko odmienne wizje relacji dwustronnych, ale także wizję przeobrażeń relacji regionalnych. W ten sposób narastała wrogość, która była tak znacząca, iż obie strony były zdolne do zastosowania całości sił i środków, jakimi dysponowały. Ponieważ potęga Rosji jako mocarstwa światowego była większa, zastosowała ona najpierw całe spektrum działań ekonomicznych, politycznych i dyplomatycznych wymierzonych w Gruzję. W dodatku z dużym prawdopodobieństwem rosyjskie służby specjalne, zapewne zarówno wojskowe, jak i cywilne, infiltrowały oraz prowadziły działania wywiadowcze ukierunkowane na osłabienie po-

${ }^{21}$ Zob. szerzej: Georgia Train and Equip program (GTEP), GlobalSecurity.org, http://www.globalsecurity.org/military/ops/gtep.htm (17.08.2009); Georgia Security \&Stability Operations (Georgia SSOP), GlobalSecurity.org, http://www.globalsecurity.org/military/ops/gssop.htm (17.08.2009).

${ }_{22}$ „W proces szkolenia wojsk gruzińskich, a zwłaszcza sił specjalnych, mocno zaangażowali się byli wyżsi oficerowie armii izraelskiej tacy jak gen. Izrael Ziv czy gen. Gal Hirsch [...]. W procesie szkolenia wojsk gruzińskich brał udział także gen. Yoram Yair i inni wysocy oficerowie Shin Bet (Izraelska Służba Bezpieczeństwa Wewnętrznego), członkowie pododdziałów antyterrorystycznych policji oraz reprezentanci firm Rafael oraz Elbit. Szacuje się, że na terytorium Gruzji mogło przebywać od 100 do nawet 1000 izraelskich instruktorów. Pojawiają się nawet nieoficjalne informacje, że gen. Hirsch (ewentualnie inni izraelscy oficerowie) mógł współuczestniczyć w planowaniu ataku na Osetię Płd.” Cyt. za: M. Gawęda, Wojska gruzińskie w wojnie z Rosja, op. cit., s. 50. 
zycji gruzińskiej. Gruzja odpowiedziała w stanowczy sposób, gdyż kładąc na szalę swoje dobre relacje z USA oraz przechodzące proces modernizacji siły zbrojne, zaangażowała się w operację wojskową w Osetii Płd.

\section{PRZEBIEG WOJNY SIERPNIOWEJ 2008 ROKU}

Punktem krytycznym stała się tzw. wojna sierpniowa z 2008 roku, w trakcie której naprzeciwko siebie stanęły siły zbrojne Gruzji i jednostki Federacji Rosyjskiej, wzmocnione formacjami pochodzącymi z Osetii Płd. i Abchazji. Działania wojenne zostały rozpoczęte w nocy z 7 na 8 sierpnia 2008 roku. Wówczas strona gruzińska przeprowadziła atak artyleryjski, który miał osłabić pozycje obronne sił rosyjsko-osetyjskich, które znajdowały się na kierunku przyszłego uderzenia gruzińskich wojsk lądowych. Istotnym elementem działań wojsk gruzińskich, który był podkreślany później przez stronę rosyjsko-osetyjską, był fakt, że ostrzałem objęte zostało również samo miasto Cchinwali. Nawała artyleryjska przeprowadzona została z użyciem całej gamy środków bojowych, jakimi dysponowała wówczas Gruzja, począwszy od systemów rakietowych aż do moździerzy ${ }^{23}$. Skomasowanie sił i środków na granicy z Osetią Płd. wyklucza jakąkolwiek przypadkowość rozpoczęcia wymiany ognia i wskazuje na dążenie strony gruzińskiej do zainicjowania ataku. Warto nadmienić, iż w gruzińskim oficjalnym kalendarium wojny, atak w nocy z 7 na 8 sierpnia 2008 roku został przedstawiony jako forma odpowiedzi z jednej strony na ataki bombowe na siły bezpieczeństwa Gruzji, a z drugiej na wymiany ognia, do jakich dochodziło $\mathrm{z}$ formacjami pochodzącymi z Osetii Płd. Jednocześnie Gruzja podkreśliła fakt reakcji na ostrzał artyleryjski, głównie moździerzowy, prowadzony ze strony sił Osetii Południowej w dniach poprzedzających rozpoczęcie działań wojennych. Szczególnie strona gruzińska podkreśla wydarzenia z 4 i 5 sierpnia 2008 roku: ,w ciagu tych dwu dni separatyści osetyjscy ostrzeliwują z terenów kontrolowanych przez rosyjskie siły pokojowe, wioski zamieszkałe przez Gruzinów lojalnych względem legalnych, pro gruzińskich władz autonomicznej prowincji. [...] 6 sierpnia 2008 r. [...] O godz. 20.00 separatyści otworzyli ogień moździerzowy w kierunku zamieszkałych przez Gruzinów wiosek: Eredwi, Prisi, Awnewi, Dwani i Nuli. Gruzińskie siły rządowe odpowiedziały ogniem celem obrony ludności cywilnej i swoich pozycji [...]"24. Jednakże w kontekście trudnych relacji na styku Osetii Płd. i Gruzji występujących w przeszłości, kiedy to nie raz dochodziło do podobnych incydentów z wymianą ognia, nie można tego traktować jako istotnego

23 Szczególną rolę odegrała gruzińska samodzielna brygada artylerii. „Brygada artylerii [gruzińska - JR], której stan liczebny szacowany był przez Rosjan na ok. 800 żołnierzy, dysponować miała ok. 40 samobieżnymi armatami i armatohaubicami (6 [szt. - JR] $203 \mathrm{~mm}$ 2S7 Pion, $24152 \mathrm{~mm}$ vz. 77 Dana, $13152 \mathrm{~mm}$ 2S3 Akacija, $1152 \mathrm{~mm}$ 2S19 Msta-S), polowymi wyrzutniami rakietowymi (m.in. 16 BM-21 Grad), a także licznymi armatami i haubicami holowanymi (m.in. $40100 \mathrm{~mm}$ armat MT-12 i $11152 \mathrm{~mm}$ haubicoarmat 2A65 Msta-B) oraz uniwersalnymi transporterami gąsienicowymi MT-LB, a także armatami przeciwlotniczymi ZU-23-2". Cyt. za: M. Gawęda, Wojska gruzińskie $w$ wojnie z Rosja, „Nowa Technika Wojskowa” 2008, nr 11, s. 53.

${ }^{24}$ Kalendarium działań wojennych na terenie Gruzji, oprac. na podstawie materiałów Ambasady Gruzji przy Unii Europejskiej, „Międzynarodowy Przegląd Polityczny” 2008, nr 3, s. 33. 
casus belli właśnie w sierpniu 2008 roku. O zainicjowaniu działań przez stronę gruzińską świadczył również fakt, że bezpośrednio po ostrzale artyleryjskim do ataku ruszyło silne zgrupowanie lądowe wojsk gruzińskich, na czele z 4 Brygadą Piechoty, którą wspierały czołgi z batalionu pancernego wojsk gruzińskich. 8 sierpnia, po ataku artyleryjskim i wyprowadzeniu uderzenia lądowego, siły gruzińskie rozbiły większość obrońców Cchinwali. Jednak miasto nie zostało całkowicie oczyszczone z obrońców, którzy bronili odizolowanych punktów oporu. Tezę, że Gruzja rozpoczęła na pełną skalę działania bojowe, udowodniło również użycie gruzińskiego lotnictwa bojowego do wsparcia własnych wojsk. Dla rozwoju dalszych wypadków szczególnie istotne okazało się, że w pierwszym dniu gruzińskiej operacji w Osetii Południowej znaczne straty poniósł rosyjski batalion sił pokojowych ${ }^{25}$, który przyjął w pewnym momencie na swoje linie obrony główny ciężar ofensywy gruzińskiej. Tak zdecydowane działania wojsk gruzińskich wobec jednostek rosyjskich w Osetii Płd., chociaż niewątpliwe uprawnione z punktu widzenia gruzińskiej operacji militarnej, musiały jednak wymusić natychmiastowe kontruderzenie ze strony sił rosyjskich rozlokowanych $\mathrm{w}$ regionie. Już 8 sierpnia, jeszcze w okresie sukcesów taktycznych wojsk gruzińskich do akcji weszło rosyjskie lotnictwo, artyleria, a w kierunku Cchinwali ruszyły pierwsze wydzielone formacje z 19. Dywizji Zmechanizowanej 58. Armii Federacji Rosyjskiej. Widoczne było już, że o ile w pierwszym momencie Gruzini uzyskali przewagę w związku z zaskoczeniem i skomasowaniem własnych wojsk na kierunku uderzenia, to jednak Rosja zamierza odbić siłą Osetię Płd. i w tym celu wykorzysta własną przewagę liczebną oraz w ilości uzbrojenia. 9 sierpnia nowe oddziały rosyjskie dotarły już do rubieży Cchinwali, przebijając się nawet z zaopatrzeniem do okrazżonych punktów oporu w samym mieście. Ponadto wojska gruzińskie, po zaciętej walce z Rosjanami, nie zdołały odciąć linii zaopatrzeniowych wojsk rosyjskich walczących w rejonie Cchinwali i wejść na ich tyły. Każda godzina walk prowadziła bezpośrednio do wzmocnienia sił rosyjskich i wytrącenia inicjatywy z rąk wojsk gruzińskich, które nie dysponowały tak rozbudowanym zapleczem. Nie oznaczało to jednak, że wojska gruzińskie, lepiej wyszkolone i częstokroć lepiej wyposażone, nie odniosły znaczących sukcesów na płaszczyźnie taktycznej. Dobitnym przykładem możliwości zadawania znacznych strat wkraczającym do Osetii Płd. siłom rosyjskim, była udana zasadzka na sztab 58. Armii, wykonana przez elitarne jednostki gruzińskiego Specnazu ${ }^{26}$. Obok działań w Osetii Płd. pole walki objęło także samo terytorium Gruzji, gdzie doszło do bombardowań lotnictwa rosyjskiego. Również na Morzu Czarnym aktywną blokadę wybrzeży Gruzji rozpoczęły okręty wojenne Federacji Rosyjskiej, należące do zgrupowania Floty Czarnomorskiej. 10 sierpnia działania sił rosyjsko-osetyjskich skoncentrowały się bezpośrednio na odbiciu z rąk gruzińskich zajętego wcześniej terytorium Osetii Płd. Doszło do walk o silnym natężeniu m.in. w mieście Cchinwali. Na Morzu Czarnym floty obu walczących

25 „Do chwili rozpoczęcia walk na terenie Osetii Południowej stacjonował batalion rosyjskich sił pokojowych liczący ok. 500 ludzi, wspierany przez nieliczne czołgi T-55 oraz bojowe wozy piechoty BMP-1/-2 i kołowe transportery opancerzone BTR-70/-80”. Cyt. za: M. Gawęda, Wojska rosyjskie w wojnie z Gruzja, „Nowa Technika Wojskowa” 2008, nr 10, s. 48.

${ }_{26} \mathrm{~W}$ państwach postradzieckich kultywowane jest nazewnictwo oddziałów operacji specjalnych, odnoszące się bezpośrednio do formacji powstałych w okresie ZSRR pod kuratelą wywiadu wojskowego GRU. W ten sposób mamy do czynienia z gruzińskim Specnazem czy też białoruskim Specnazem. 
stron nawiązały kontakt bojowy i starły się ze sobą w potyczce morskiej ${ }^{27}$. Stopniowo, wraz z rozrostem potęgi militarnej Federacji Rosyjskiej w rejonie walk, uwidocznił się zupełny pat decyzyjny w łonie polityczno-wojskowych władz Gruzji. Zabrakło decyzji kształtujących dalszą strategię postępowania strony gruzińskiej, co w przypadku wejścia do walki nowych jednostek rosyjskich wprowadziło w późniejszym etapie działań chaos w siłach gruzińskich. 11 sierpnia w rejonie ufortyfikowanej wsi Zemo Nikozi, wojska gruzińskie po raz kolejny wykazały możliwości bojowe, doprowadzając do znacznych strat po stronie rosyjskiej. Jednak cały czas to Gruzini byli zmuszeni do ciągłego wycofywania się z zajętych wcześniej pozycji. Odwrót sił gruzińskich, wzmocnionych rezerwistami o słabym morale, finalnie 11 sierpnia przerodził się w ucieczkę. Skutkiem takiego postępowania sił gruzińskich, było zupełne rozproszenie się jednostek i utracenie przy tym znacznych ilości sprzętu bojowego. Decyzją prezydenta Micheila Saakaszwiliego postanowiono o utworzeniu nowej linii obrony, na potencjalnej drodze ataku rosyjskiego na stolicę Tbilisi. W praktyce terytorium Gruzji jednak stanęło otwarte i pozbawione obrony, w oczekiwaniu na wkroczenie wojsk rosyjskich. Sytuacji nie poprawiła nawet operacja amerykańska przetransportowania do Gruzji elitarnego kontyngentu wojsk gruzińskich, które do tego momentu działały w Iraku. „Mimo gromkich zapewnień prezydenta [M. Saakaszwiliego - JR], nie przygotowywano jednak stolicy do obrony - nie kopano okopów, nie tworzono barykad, stanowisk ogniowych, nie zakładano pól minowych. Gruzja nie ma wielkiej ilości dróg, po których mogą poruszać się kolumny pancerne, a wzgórza i wąwozy są idealnym miejscem, gdzie można prowadzić obronę, minując drogi i blokując ogniem ważne węzły drogowe. Co więcej pomiędzy Gori a Tbilisi przez pewien czas nie było ani jednego posterunku czy też pozycji przesłonowej [... $]^{\text {"28 }}$. W obliczu braku oporu militarnego strony gruzińskiej, terytorium Gruzji zostało spenetrowane przez formacje należące do wojsk rosyjskich. Działania objęły wówczas nie tylko znajdujące się w bliskiej odległości od Osetii Płd. miasto Gori, ale także bardzo ważne instalacje militarne i cywilne znajdujące się m.in. w porcie w Poti czy też w gruzińskiej bazie wojskowej w Senaki ${ }^{29}$. Nowym elementem działań stało się rozszerzenie strefy działań rosyjskich o kierunek abchaski $^{30}$. W związku z tym, że działania w Osetii Płd. rozbiły trzon sił gruzińskich zarówno dla Federacji Rosyjskiej, jak i Abchazji zaistniała możliwość odzyskania kontroli nad strategicznym Wąwozem Kodori. Siły rosyjskie współdziałając z jednostkami abchaskimi przejęły panowanie nad zajmowanymi wcześniej przez siły gruzińskie pozycjami w rejonie Kodori, zmuszając stacjonujących tam Gruzinów do odwrotu ${ }^{31}$. Siły

27 O działaniach morskich zob. szerzej: M. Nałęcz, Morze Czarne - Rosja vs. Gruzja, „Nowa Technika Wojskowa" 2008, nr 10, s. 57-59.

${ }_{28}$ T. Szulc, Zaktamana wojna, „Raport Wojsko-Technika-Obronność” 2008, nr 9, s. 16.

${ }_{29}$ Gruzińskie ośrodki miejskie, a przede wszystkim kluczowe dla gospodarki instalacje cywilne oraz wojskowe były przez długi okres czasu nękane przez rajdy wojsk rosyjskich. Zob. szerzej: $K a-$ lendarium działań wojennych na terenie Gruzji, oprac. na podstawie materiałów Ambasady Gruzji przy Unii Europejskiej, op. cit., s. 40-47.

30 Zob.: Abkhazia, GlobalSecurity.org, http://www.globalsecurity.org/military/world/war/abkhazia.htm (17.08.2009).

31 Rosjanie podkreślali, iż Gruzja przygotowywała właśnie z rejonu Kodori atak, podobny do tego jaki miał miejsce kilka dni wcześniej w Osetii Płd. „Według informacji zdobytych przez Rosjan 
rosyjskie pod koniec wojny dysponowały pełnią inicjatywy strategicznej na każdym kierunku działania. Można uznać, że jedynym istotnym punktem symbolicznego oporu i to raczej skupionego na płaszczyźnie politycznej strony gruzińskiej, była wówczas stolica Tbilisi. Istnieje przekonanie, że nie doszło do zajęcia stolicy Gruzji z racji zorganizowania tam wiecu poparcia dla władz gruzińskich, w którym wzięli udział prezydenci Polski, Litwy, Łotwy i Ukrainy ${ }^{32}$. Bardziej prawdopodobne wydaje się jednak, że politycy i głównodowodzący rosyjscy uznali, iż w obliczu faktu osiagnięcia założeń strategicznych próba zajęcia stolicy Gruzji mogłaby okazać się zbyt kosztowna, nie tyle nawet w sensie militarnym, co raczej politycznym. Ponadto większość terytorium Gruzji i tak znajdowała się pod okupacją rosyjską. Konflikt zbrojny został wygaszony poprzez działania dyplomatyczne. Pomimo zakończenia głównych działań bojowych dochodziło m.in. do licznych aktów przemocy w Osetii Płd., gdzie formacje paramilitarne atakowały nastawione pro gruzińsko enklawy ludności. Za ostateczny moment zakończenia wojny można uznać podpisanie przez walczące strony, przy bezpośredniej mediacji prezydenta Francji Nicolasa Sarkozyego, porozumienia o zawieszeniu bro$\mathrm{ni}^{33}$. Jednakże strona gruzińska wielokrotnie wskazywała na łamanie podpisanego porozumienia przez siły rosyjskie, chociażby w kwestii opuszczania przez nie terytorium Gruzji. Pomimo zakończenia działań zbrojnych stan napięcia na spornych terytoriach utrzymuje się nadal, stwarzając realne zagrożenie dla stabilności nie tylko Gruzji.

$* * *$

Wnioski płynące z obserwacji działań wojennych w Gruzji w 2008 r. można odnieść nie tylko do samego regionu Kaukazu, ale również do szerzej pojmowanej dziedziny bezpieczeństwa narodowego. W aspekcie regionalnym polityka gruzińska odniosła porażkę w perspektywie krótkoterminowej. Przede wszystkim podstawowy problem, jakim było oderwanie spornych terytoriów od Gruzji stało się faktem. W dodatku możliwość przywrócenia władzy gruzińskiej w Osetii Płd. czy też Abchazji, w formie chociażby autonomii w ramach Gruzji, jest w najbliższym czasie raczej niemożliwe. Jednakże należy wskazać, że oba regiony pozostawały poza kontrolą Gruzji od początku lat dziewięćdziesiątych XX w. i nie stanowiły ważnego elementu w gospodarce gruzińskiej, tak więc ich utrata nie wpłynie choćby na pogorszenie się wskaźników ekonomicznych państwa. Jasne i klarowne opowiedzenie się Federacji Rosyjskiej za

11 sierpnia planowano zaatakować Abchazję na trzech kierunkach siłami ok. 1,5 brygady wspartej przez artylerię i ciężki sprzęt. Trudno powiedzieć na ile są to wiadomości prawdziwe, tym bardziej, że Siły Zbrojne Abchazji są znacznie silniejsze niż osetyjskie i stacjonowało tam więcej Rosjan z sił pokojowych". Cyt. za: M. Gawęda, Wojska rosyjskie w..., op. cit., s. 50.

32 Zob. szerzej: M. Czech, To byta noc Lecha Kaczyńskiego, „Gazeta Wyborcza”, 5.09.2008, wydanie internetowe, http://wyborcza.pl/1,87648,5660891,To_byla_noc_Lecha_Kaczynskiego.html (17.08.2009); Tibilisi czeka na prezydentów, „Wprost”, 12.08.2008, wydanie internetowe, http://www.wprost.pl/ar/136181/Tibilisi-czeka-na-prezydentow (17.08.2009).

33 Porozumienie o zawieszeniu broni składało się z tzw. sześciopunktowego porozumienia z 12 sierpnia 2008 r. oraz uzupełniającego trzypunktowego z 8 września 2008 r. Zob. szerzej o porozumieniu pokojowym: Rok po wojnie rosyjsko-gruzińskiej. Stan realizacji porozumień Sarkozy-Miedwiediew z 12 sieprnia 2008 r. oraz 8 września 2008 r., oprac. K. Zasztowt, Analiza Biura Bezpieczeństwa Narodowego, 10.08.2009, s. 1-5. 
niepodległością Abchazji i Osetii Płd. wyeliminowało podstawową rosyjską kartę przetargową w stosunkach z władzami gruzińskimi. Gruzja, wykorzystując chociażby przykład Serbii, która utraciła władzę nad Kosowem, może w kontaktach z partnerami zachodnimi wykazywać, iż problem abchaski oraz osetyjski, który wcześniej był głównym powodem hamowania zbliżenia, jest po przegranej wojnie zdecydowanie mniej istotny. W dłuższej perspektywie czasowej taka sytuacja może być nawet pomocna w zbliżeniu Gruzji ze strukturami UE i NATO ${ }^{34}$. Gruzja zapewne będzie odwoływała się do swych praw w kontekście pogwałcenia nienaruszalności terytorium państwa przez Rosję, jednak jeżeli nastapi szybkie zaakceptowanie nowej sytuacji może to znacząco poprawić pozycję Gruzji w rozmowach np. z UE czy też NATO. Jednocześnie Federacja Rosyjska została zmuszona do pełnego wspierania w wielu dziedzinach dwóch de facto nowych państw, których potencjał ekonomiczny wskazuje raczej na potrzebę utrzymywania znaczącej pomocy finansowej ze strony rosyjskiej. Przegrana wojna wykazała również, że rozwiązanie siłowe okazało się mniej skuteczne aniżeli wywieranie presji na społeczeństwo, jak to miało miejsce w przypadku Adżarii. Należy domniemywać, iż w przypadku umiejętnego oddziaływania przez Gruzję na ludność zamieszkującą przede wszystkim Osetię Płd. możliwe było doprowadzenie do podobnych wprowadzanych stopniowo zmian, jakie zaszły bezkrwawo w Adżarii. Można przypuszczać, że wpływ na podjęcie przez stronę gruzińską decyzji o rozpoczęciu ofensywy miały raczej nie tyle przesłanki strategiczne, o czym świadczy brak planów na wypadek kontrofensywy rosyjskiej, ale raczej problemy wewnętrzne, których rozwiązania szukano w zwycięskiej wojnie. Federacja Rosyjska osiagnęła bezsprzecznie sukces militarny, pokonując gruzińskie siły zbrojne i wkraczając na terytorium Gruzji. Jednak nie obyło się bez ukazania znacznych słabości sił rosyjskich, których nie można było kamuflować w przypadku prowadzenia otwartej ofensywy militarnej. Rosja w krótkiej perspektywie odbudowała także pozycję mocarstwa zdolnego do aktywnego wymuszania własnej woli na innych państwach ${ }^{35}$. W obliczu zwycięstwa podkreślona została rola Rosji jako hegemona na Kaukazie, ale i w tym zakresie można wnioskować, że w perspektywie długookresowej zarówno Gruzja, jak i inne państwa będą szukały zrównoważenia potęgi rosyjskiej. Możliwym scenariuszem jest zbliżenie państw Kaukazu np. w kierunku ChRL, szczególnie, że w tle takich działań pojawiłby się aspekt surowcowy. Klęska gruzińska niewątpliwie najmocniej nadszarpnęła wizerunek i pozycję Stanów Zjednoczonych w regionie. USA uznawane za

34 Partnerzy Gruzji na Zachodzie wskazywali nierozwiązaną kwestię Osetii Płd. i Abchazji jako główny powód niestabilności gruzińskiej i tym faktem było wyjaśniane negatywne nastawienie do prowadzenia z Gruzją bardziej konkretnych rozmów np. w kwestii przystapienia do NATO.

35 Działania w Gruzji mogą być uznawane nie tylko za próbę chwilowego utrzymania własnej strefy wpływów, ale także jako element pozycjonowania Rosji, jako mocarstwa, na początku XXI w. Jeden z głównych rosyjskich politologów Gleb Pawłowski w 2006 roku stwierdził w wywiadzie dla „Nowego Państwa” - „Rosja stara się wrócić na właściwe dla niej miejsce w świecie, a zawsze ono było i będzie wyjątkowe, choćby ze względu na położenie i wielkość naszego kraju. Dla Rosji pozostaje istotne także to, by znów stać się ważną dla świata, potrzebuje bowiem poczucia wewnętrznej siły. [...] Rosja nie pragnie walki, ale chce być uznawana za czołowe państwo na terenie byłego ZSRR i chce mieć stosowne do tego wpływy. Jestem przekonany, iż z czasem będą one rosnąć. [...]". Cyt. za: Moskwa nie chce budować imperium, wywiad z Glebem Pawłowskim przeprowadzony przez V. Dunaeva, „Nowe Państwo” 2006, nr 3, s. 97. 
głównego sojusznika Gruzji nie wykazały odpowiedniej aktywności w momencie zagrożenia terytorium gruzińskiego. Takie zachowanie Stanów Zjednoczonych stworzyło również płaszczyznę do ekspansji UE w regionie. Pozycję UE wzmocnić może odwoływanie się do tzw. soft power, która będzie skuteczniejsza w obliczu niepowodzenia militarnych działań gruzińskich. Ponadto w przeciwieństwie do USA, które są zwrócone w zakresie pozyskiwania surowców naturalnych raczej w kierunku Bliskiego Wschodu, a nawet Afryki, UE jest najbardziej obok Rosji zainteresowana dostępem do złóż i sieci transportowych Kaukazu. UE ma także potencjalnie, z racji bycia największym odbiorcą surowców rosyjskich, mocniejszą pozycję w kontaktach z Federacją Rosyjską. Dlatego łatwiejsze byłoby zbliżenie państw regionu właśnie do UE, aniżeli analogicznie do NATO. Interesującym doświadczeniem wojny z 2008 r. może być pragmatyczna polityka Izraela. Izraelczycy, jako naturalni sojusznicy USA, wpisali się na trwałe w rozbudowę sił zbrojnych Gruzji rozpoczętą gwałtownie po 2003 roku. Jednak dostrzegając chwiejną postawę USA i w obliczu klęski gruzińskiej, Izrael pragmatycznie zdołał wykorzystać własną aktywność w Gruzji dla polepszenia relacji z Federacją Rosyjską chociażby w kontekście programu atomowego Iranu.

W szerszym niż regionalny kontekście, wojna z 2008 roku wykazała, że państwa powinny dysponować przede wszystkim skuteczną strategią obronną, bazującą na dokładnym rozważeniu własnych sił i środków. Gruzja decydując się na działania militarne, szczegółowo zaplanowała pierwszy etap ofensywy, bazujący na szybkości i zaskoczeniu przeciwnika-zakończył się on sukcesem w postaci postępów na terytorium Osetii Płd. Jednak w miarę rozwoju sytuacji na froncie, postępowanie gruzińskich władz politycznych i wojskowych wykazywało oznaki coraz większego kryzysu decyzyjnego, czy nawet wręcz chaosu. Finalnie niemożliwym do zaakceptowania stał się fakt, że terytorium Gruzji pozostało bez obrony. Symboliczne było zachowanie prezydenta Gruzji M. Saakaszwiliego, który będąc obecnym w telewizji w trakcie działań wojennych, gryzł ze zdenerwowania własny krawat. Strategia obrony powinna być podbudowana konstrukcją sprawnych i skutecznych sił zbrojnych. Gruzińskie siły zbrojne nie potrafiły odpowiednio zbalansować środków przeznaczanych na ich restrukturyzację i rozwój. Siły zbrojne Gruzji miały być nieliczne, ale za to profesjonalne i bardzo dobrze wyposażone. W ten sposób powstał rozdział na jednostki przygotowane do działań oraz te, których pojawienie się na froncie doprowadziło raczej do osłabienia działań sił gruzińskich. Należy zastanowić się, czy w obliczu chociażby reformy polskich sił zbrojnych, nie należałoby wziąć pod uwagę doświadczeń gruzińskich, w szczególności tych dotyczących odpowiedniego przygotowania i wyposażenia jednostek drugiej linii, znajdujących się w rezerwie strategicznej. Przypadek Gruzji ukazuje, jak istotne jest rozsądne gospodarowanie siłami wysyłanymi na misje poza granice państwa. Gruzini dyslokowali do Iraku kontyngent liczący prawie dwa tysiące żołnierzy, którzy nie byliby w stanie bez pomocy amerykańskiego lotnictwa transportowego wrócić do swego państwa. Należy zaznaczyć, że siły gruzińskie w Iraku, stanowili żołnierze lepiej wyszkoleni i wyposażeni, niż ci, na których spoczęła obrona zajętych obszarów Osetii Płd. w miarę wykruszania się w walkach oddziałów pierwszego rzutu. Dlatego ich brak w przypadku niezbyt licznych sił zbrojnych Gruzji był odczuwalny. Po raz kolejny należałoby m.in. dokładniej przeanalizować sposób i strategię wysyłania polskich sił na różnego rodzaju misje zagraniczne (stabilizacyjne, 
pokojowe, humanitarne itp.). Działania wojenne w Gruzji dostarczyły cennych wniosków w kontekście potrzeby rozwoju sił operacji specjalnych. Obie strony używały własnych oddziałów elitarnych z bardzo dobrym skutkiem, odnosząc liczne sukcesy w trakcie wspierania działań głównych sił uderzeniowych. Wykazana została także potrzeba dysponowania odpowiednim wyposażeniem, które w sytuacji dysproporcji liczebności sił i środków mogło zniwelować braki ilościowe. Szczególnie ważne w tym kontekście wydaje się zapewnienie państwu sprawnego systemu obrony przeciwlotniczej. Co istotne, skuteczne uzbrojenie nie musi być jednoznacznie kojarzone z produkowanym tylko w USA oraz państwach Zachodu. Gruzja oprócz uzbrojenia pochodzącego z USA czy też Izraela, inwestowała chociażby w bardzo skuteczne systemy przeciwlotnicze produkcji ukraińskiej. Jednakże błędne byłoby myślenie, że sama przewaga technologiczna jest w stanie zrównoważyć dysproporcję sił i środków bojowych, która wystąpiła w przypadku konfliktu gruzińsko-rosyjskiego. Można się zgodzić z niektórymi obserwatorami rosyjskimi, którzy twierdzili, że przeszczepianie amerykańskiego modelu sił zbrojnych do innych państw nie jest warunkiem odnoszenia zwycięstw ${ }^{36}$. Należałoby uznać, iż idealnym jest czerpanie z doświadczeń zarówno amerykańskich lub ogólniej zachodnich, ale bez pomijania cennych elementów pochodzących z Rosji czy też ChRL. Na koniec należałoby zastanowić się nad kwestią odpowiedniego zawierania sojuszy przez państwa mniejsze. Gruzja podjęła się działań mając na uwadze bliskie relacje z USA, które jednak nie wpłynęły w sposób znaczący na zatrzymanie rosyjskiej odpowiedzi militarnej, a być możne nawet ją zwiększyły $\mathrm{w}$ celu niejako upokorzenia największego amerykańskiego sojusznika w regionie. Można więc wnioskować, że kluczowe dla zachowania bezpieczeństwa państwa, jest przede wszystkim jasne i pragmatyczne postrzeganie więzi sojuszniczych. Im są one mniej doprecyzowane i podbudowane wspólnym interesem obu stron, tym bardziej należy zachowywać do nich dystans.

Wojna z 2008 roku między Federacją Rosyjską a Gruzją nie może być postrzegana jako punkt przełomowy w kształtowaniu się relacji regionalnych czy też globalnych. Jednakże, ponieważ doszło do działań zbrojnych, które są zawsze ostatecznością, można łatwiej dostrzec elementy konstytuujące trwałe tendencje w regionie. Należy zaznaczyć, że na początku XXI w. jasno widać, iż rola sił zbrojnych w rozwiązywaniu sporów między państwami nie zmalała i nadal aktualnym w stosunkach międzynarodowych pozostaje stwierdzenie si vis pacem, para bellum ${ }^{37}$.

${ }^{36}$ Błędne byłoby także zgodzenie się z tezą, iż wojna wykazała wielką skuteczność sił rosyjskich w obliczu amerykańskiego modelu sił zbrojnych, jak wskazuje chociażby w „Moscow Defense Brief” Mikhail Barabanov. Siły rosyjskie borykały się m.in. z problemami skutecznej komunikacji pomiędzy własnymi oddziałami, brakowało odpowiednich środków rozpoznania, część jednostek była źle wyposażona, popełniano błędy na płaszczyźnie taktycznej. Jednakże należy też dodać, że Federacja Rosyjska była skutecznie na płaszczyźnie strategicznej przygotowana do odpowiedzi na interwencję gruzińską. Jej siła i czas reakcji była zaskoczeniem dla strony gruzińskiej. Zob.: M. Barabanov, The August War between Russia and Georgia, „Moscow Defense Brief”, wydanie internetowe http://mdb.cast.ru/mdb/3-2008/item3/article1/ (17.08.2009).

37 Łac. jeżeli chcesz pokoju, gotuj się do wojny. 


\title{
STRESZCZENIE
}

Celem artykułu jest ukazanie struktury wojny toczonej przez Gruzję i Federację Rosyjską na terytorium separatystycznej republiki Południowej Osetii. Autor przedstawił tło konfliktu poprzez nakreślenie sieci głównych zależności w regionie. Jednocześnie Autor zaprezentował podstawowe kierunki rywalizacji w rosyjskiej i gruzińskiej polityce, które później stały się przyczyną wybuchu otwartego konfliktu zbrojnego w 2008 r. Artykuł zawiera także rozważania na temat wpływu wojny na stan bezpieczeństwa w regionie.

\section{THE INFLUENCE OF THE 2008 CONFLICT IN GEORGIA ON A MODERN VISION OF INTERNATIONAL SECURITY. SELECTED ASPECTS}

\begin{abstract}
The aim of this article is to highlight a structure of war between Georgia and Russia over South Ossetia separatist republic. The author describs background of the conflict by showing main interdependencies in region. Simultaneously, the author presents main rivalry directions in Russian and Georgian policy which were main reasons behind the outbreak of military conflict in 2008. This article also contains considerations about potential influences of war on the security status in the region.
\end{abstract}


